\title{
WRITINGS BY PHILOLOGISTS OF THE PAST AS A BASIS FOR SHAPING LINGUISTIC PERSONALITY OF A MODERN TEACHER
}

\author{
ESCRITOS DE FILÓLOGOS DO PASSADO COMO BASE PARA A FORMAÇÃO DA \\ PERSONALIDADE LINGUÍSTICA DE UM PROFESSOR MODERNO
}

\author{
ESCRITOS DE FILÓLOGOS DEL PASADO COMO BASE PARA FORMAR LA \\ PERSONALIDAD LINGÜÍSTICA DE UN MAESTRO MODERNO
}

\author{
Olga Leonidovna ARISKINA ${ }^{1}$ \\ Elena Anatolyevna DRYANGINA ${ }^{2}$ \\ Gulnara LUTFULLINA ${ }^{3}$
}

\begin{abstract}
The objective of this article is to analyze Apollos' linguistic personality and answer the question whether the linguistic personality of a priest-scholar, author of grammar writings, public figure of the 18th century can be exemplary during the formation of a modern educator's linguistic personality. To solve the declared problem, a comparative analysis between the linguistic personality of the modern Russian teacher and the scholar of the past's was done. This became possible due to the use of sociolinguistic methods - questionnaire survey and interview, as well as to the use of Yu. N. Karaulov method of analysis of linguistic personality, M.K. Petrov concept of sociocode and G. Lakoff cognitive metaphor theory. The main findings of the research: 1) it has revealed problems of modern education; 2) identified and described Apollos' value orientations, transmitted to students; 3) formulated a scientific hypothesis: it is necessary to use the writings of linguists/philologists and educators of the past as a basis for the formation of linguistic personality of a modern educator, tutor, mentor, facilitator because linguistic personality of previous centuries' scholars and methodologists can be recognized as a model linguistic personality for a teacher of Russian language and literature. The research findings can be introduced to a number of academic disciplines such as "Educator's professional personality", "Sociolinguistics", "Cultural linguistics", "Communicative-speech training", "Academic eloquence", "Genres of academic discourse", "Stylistics", "Russian language in the sociolinguistic aspect", "Sociolinguistic foundations of communication" etc., they will also be essential in developing continuing (lifelong) education courses for teaching staff specializing in "Linguistic personality of a tutor: history and contemporaneity". The novelty and originality of this research stems from the fact that 1) the analysis of pedagogical discourse was carried out in two time slices - year of 2019 and 18th century, that allowed to reveal the specificity of a Russian language and literature teacher's linguistic personality in synchrony and diachrony, 2) Apollos' grammar was for the first time
\end{abstract}

${ }^{1}$ Ogarev Mordovia State University (MRSU), Saransk - Russia. Professor of the Department of Russian as a Foreign Language. Doctor of Philology. ORCID: https://orcid.org/0000-0001-5716-8881. E-mail: ariskina.o@bk.ru

${ }^{2}$ Ogarev Mordovia State University (MRSU), Saransk - Russia. Associate Professor of the Department of Russian as a Foreign Language. ORCID: https://orcid.org/0000-0003-1646-9658. E-mail: lasina.83@mail.ru

${ }^{3}$ Kazan State Power Engineering University (KSPEU), Kazan - Russia. Associate Professor of the Department of Foreign Languages. Doctor of Philology. ORCID: https://orcid.org/0000-0003-1572-5314. E-mail: gflutfullina@mail.ru 
explored within the anthropocentric paradigm, 3) the prospects for further study are seen in taking from the best of the past philology to the matrix of modern education.

KEYWORDS: Apollos. Grammar book. Discourse. Metaphor. Concept.

RESUMO: O objetivo deste artigo é analisar a personalidade linguística de Apollos e responder se a personalidade linguística de um sacerdote-erudito, autor de textos gramaticais, figura pública do século XVIII pode ser exemplo durante a formação da personalidade linguística de um educador moderno. Para resolver o problema declarado, uma análise comparativa do professor russo moderno com o estudioso da personalidade linguística do passado foi feita. Isso se tornou possível devido ao uso de métodos sociolinguísticos - questionário de pesquisa e entrevista, bem como ao uso do método de análise da personalidade linguística de Yu. N. Karaulov, conceito de sociocódigo de M.K. Petrov e teoria da metáfora cognitiva de G. Lakoff. Os principais resultados da pesquisa: 1) revelou problemas da educação moderna; 2) identificou e descreveu as orientações de valor de Apollos, transmitidas aos alunos; 3) formulou uma hipótese cientifica: é necessário usar os escritos de linguistas/filólogos e educadores do passado como base para a formação da personalidade linguística de um educador, tutor, mentor, facilitador moderno porque a personalidade linguística de estudiosos e metodologistas dos séculos anteriores pode ser reconhecida como um modelo de personalidade linguística para um professor de língua e literatura russas. Os resultados da pesquisa podem ser introduzidos em uma série de disciplinas acadêmicas, como "Personalidade profissional do educador", "Sociolinguística", "Linguística cultural", "Treinamento de fala comunicativa", "Eloquência acadêmica", "Gêneros do discurso acadêmico", "Estilística", "A língua russa no aspecto sociolinguístico", "Fundamentos sociolinguísticos da comunicação" etc., também serão essenciais no desenvolvimento de cursos de educação continuada (ao longo da vida) para professores especializados em "Personalidade linguística de um tutor: história e contemporaneidade". A novidade e originalidade desta pesquisa decorre do fato de que 1) a análise do discurso pedagógico foi realizada em duas parcelas temporais - ano de 2019 e século XVIII, permitindo revelar a especificidade da personalidade linguística de um professor de literatura e língua russa em sincronia e diacronia, 2) A gramática de Apollos foi explorada pela primeira vez dentro do paradigma antropocêntrico, 3) as perspectivas para um estudo mais aprofundado são vistas ao se levar o melhor da filologia do passado para a matriz da educação moderna.

PALAVRAS-CHAVE: Apollos. Livro de gramática. Discurso. Metáfora. Conceito.

RESUMEN: El objetivo de este artículo es analizar la personalidad lingüistica de Apolos y responder a la pregunta de si la personalidad lingüística de un sacerdote erudito, autor de escritos gramaticales, figura pública del siglo XVIII puede ser ejemplar durante la formación de un educador lingüístico moderno. personalidad. Metodología. Para resolver el problema declarado, se realizó un análisis comparativo de la personalidad lingüistica del maestro ruso moderno y estudioso del pasado. Esto fue posible gracias al uso de métodos sociolingüisticos: cuestionario y entrevista, así como al uso de Yu. N. Método Karaulov de análisis de la personalidad lingüística, M.K. Concepto Petrov de sociocódigo y teoría de la metáfora cognitiva de G. Lakoff. Los principales hallazgos de la investigación: 1) ha revelado problemas de la educación moderna; 2) identificó y describió las orientaciones de valor de Apolos, transmitidas a los estudiantes; 3) formuló una hipótesis científica: es necesario 
utilizar los escritos de lingüistas / filólogos y educadores del pasado como base para la formación de la personalidad lingüistica de un educador, tutor, mentor, facilitador moderno porque la personalidad lingüistica de los eruditos de los siglos anteriores y los metodólogos pueden ser reconocidos como una personalidad lingüistica modelo para un profesor de lengua y literatura rusas. Aplicación de los resultados de la investigación. Los resultados de la investigación pueden introducirse en una serie de disciplinas académicas como "Personalidad profesional del educador", "Sociolingüistica", "Lingüistica cultural", "Entrenamiento del habla comunicativa", "Elocuencia académica", "Géneros del discurso académico", "Estilística ", " Lengua rusa en el aspecto sociolingüístico ”, " Fundamentos sociolingüisticos de la comunicación ”, etc.), también serán fundamentales en el desarrollo de cursos de formación continua (de por vida) para el profesorado especializado en " Personalidad lingüistica del tutor: historia y tiempo contemporáneo". La novedad y originalidad de esta investigación surge de que 1) el análisis del discurso pedagógico se realizó en dos franjas de tiempo, año 2019 y siglo XVIII, que permitió revelar la especificidad de la personalidad lingüistica de un profesor de lengua y literatura rusa en sincronía y diacronía, 2) la gramática de Apolos fue explorada por primera vez dentro del paradigma antropocéntrico, 3) las perspectivas de estudios posteriores se ven al llevar de lo mejor de la filología pasada a la matriz de la educación moderna.

PALABRAS CLAVE: Apolos. Libro de gramatica. Discurso. Metáfora. Concepto.

\section{Introduction}

The anthropocentric paradigm is an outstanding feature of the current humanitaristics. Philology and pedagogy are no exception (ZHELTUKHINA, 2014). B.M. Gasparov believes that language is the core medium of human existence:

Every act of using a language - whether it is a work of high artistic value or a remark in conversation in passing - constitutes a tiny bit of the moving stream of human experience. In its capacity, it absorbs and reflects the unique combination of circumstances under which and for which it was created [...] (GASPAROV, 1996, p. 10).

Modern linguists are trying to correlate the language vocabulary and its dynamics with evolution of the mankind (GRINEV, 2017). Linguists' attention is focused on human communication, on discursive strategies, on problems of linguistic manipulation (CHERNYAVSKAYA, 2006; GUMPERZ, 1982), on awareness and cognition of the linguistic/communicative/discursive/rhetorical personality (there appear more and more terminological nominations for this phenomenon every year (ARISKINA; DRYANGINA, 2011a; 2011b).

Furthermore, it is not only Russian scholars who refer to it (for example, "Personality expression in Chinese language use" (QIU et al., 2017). In this paper, we will focus on the 
term "linguistic personality", which was introduced by Karaulov (1987) in his monograph "Russian language and linguistic personality".

There are many approaches to the analysis of linguistic personality. Researchers focus on types of the linguistic ability of a linguistic personality (VORONOVA, 2014) and speech expressiveness (VALEEVA et al., 2018). Both individual and model, as defined by Karasik (2002; 2017), linguistic personalities are considered, since the analysis of the totality of linguistic personalities representing a professional community allows giving a holistic characteristic of the system of their features.

Therefore, current topics vigorously explored are linguistic/communicative personality of a journalist (ARISKINA; YURINA, 2020), talk show host (BESPAMYATNOVA, 2002), politician (ARISKINA et al., 2016), entrepreneur (TUPITSYNA, 2000), engineer (ELOKHOVA, 2016), HR manager (STOLYAROVA; FEDOTOVA, 2017), law student (LEVITAN; MEDVEDEVA, 2014; LEVITAN; YUGOVA, 2019), speech portraits of a translator (SHEVCHENKO, 2005), an intellectual (KRYSIN, 2001), a king/tsar (SHILINA, 2003), individual style of a writer (MENKOVA, 2004), educator, scholar (ARISKINA; DRYANGINA, 2020; SIVTSOVA; ARISKINA, 2013), etc.

The problem of this study can be formulated as follows: how to form a teacher's linguistic personality that would become a role model.

The analysis of teaching practices shows that the professional success of an educator is predetermined by a responsible attitude towards speech activity and the formed productive language consciousness. A teacher must be able to analyse their speech and select the means to represent their language identity, which contributes to more effective learning. Back at the end of the last century, Kan-Kalik (1987, p. 96) highlighted in his work "To a teacher on pedagogical communication": "The analysis of the activity of young teachers shows that often a well-prepared lesson, not supported by a bright, figurative speech of a teacher, does not fully realize its teaching and educational opportunities". Modern researchers also refer to the problem of the formation of linguistic/communicative personality of an educator, focusing both on its positive manifestations, such as "an adequate choice and individual implementation of certain strategies and tactics of professional speech behavior" (FILIPPOVA, 2012, p. 3), and negative, among which one of the most striking is speech aggression (KOBYAKOVA, 2012). Our hypothesis is that to solve this problem, it is necessary to use the writings of linguists and teachers of the past as a basis for shaping linguistic personality of a modern teacher. 
Linguistic personalities of such widely recognised teachers as A.S. Makarenko, M. Montessori, V.A. Sukhomlinsky, K.D. Ushinsky, and others have not been studied (COCKERILL, 2011; DRYANGINA, 2008; 2013; VORONOVA, 2014). However, in many ways, they can be referred to as exemplary, which means that, based on their analysis, it is necessary to educate, nurture, and form the modern generation of teachers.

What features should the modern linguistic personality of a teacher have so that it could be called exemplary, ideal? What is the "social order" today (Baranov, 1990)? Let us try to present such a "portrait", based on studies conducted by scholars in the 20th-21st centuries.

Vorozhbitova (1999, p. 25) believes that a strong linguistic personality is made up of high linguistic competence, which allows carrying out "thought-speaking activity in productive and receptive registers, monological and dialogic modes, oral and written forms"; we will also add - various speech genres.

Yuryeva (2002) considers naturalness, simplicity, logic, clarity, accuracy, purity, and correctness as the main qualities of a teacher's speech. At the same time, it should be emphasised that the linguistic personality of a teacher is characterised by increased selfcontrol over the correctness of speech and correction of the speech of others.

There is no unambiguous solution to the issue of using slang Shcherbinina (2010) in her book "Pedagogical discourse: think - speak - act" gives several pro and contra arguments.

Essential qualities of a teacher's speech are emotionality, richness, expressiveness, and intonational persuasiveness. Yuryeva (2002) believes that the identity of a teacher is manifested in speech due to its friendliness, truthfulness, tactfulness, and sincerity. Kan-Kalik (1987, p. 54) notes that speech must necessarily be emotionally colored by the personal attitude of a teacher to a child: "the warmth of a friendly attitude to the child ... does not reduce the pedagogical business of the whole lesson". The scholar also believes that a teacher is characterised by a good verbal memory, correct choice of linguistic means, and logical construction and presentation of a statement.

Researchers refer to the existence of general cultural, psychological, pedagogical, medico-biological, subject, and special ideas about the world around as the main components of the linguo-cognitive level (VOROZHBITOVA, 1999). The center of the system of values of a teacher's linguistic personality is a student.

One of the most important qualities of a teacher is their ability to organise interaction with children, to communicate with them, and to lead their activities... Of course, the ability to communicate with children should be 
based on a solid foundation of love for them - on what in science is called the professional and pedagogical orientation of a teacher's identity (KANKALIK,1987, p. 34).

Communication itself is also a value for the linguistic personality of the teacher, considered "both as a value-goal and as a value-means" (FROLOVA, 2009, p. 70). S.L. Frolova believes that the value of communication is based on a value attitude towards language. We should also add the thought expressed in "Methodology of teaching the Russian language" edited by M.T. Baranov (1990, p. 115):

[...] the native language is an instrument of cognitive activity, a form of thinking, and a means of its development. It is impossible to learn at a modern school without a well-developed speech skill, without the ability to express one's own thoughts, without quickly and correctly perceiving others"; "language ... makes a person a personality, includes them in social activities.

Shcherbinina (2010, p. 203), highlights "mastering knowledge and skills, continuous improvement of skills, raising the professional and qualification level, succession and continuity of knowledge transfer and mastering, etc." as the teacher's priority values.

The value of creativity is also emphasized in Martishina's (2006, p. 49) work "Value component of the creative potential of personality":

An educator, whose activity by definition is creative, must be aware of the value nature of creativity itself. It consists primarily in the ability to describe from the point of view of creativity (different in nature, personal and social coloring, extent, consequences, assessment) all three projections of the world picture (past, present, future), their comparison, connection, transition from one state to another, and multidimensionality and ambiguity of explicit and hidden causal links. Through the perspective of creativity, we see more clearly the complexity of the conceptual saturation of time and space. Here we are talking not so much about quantitative (months, years, centuries, etc.) but qualitative (culture, social relations, etc.) parameters.

The pragmatic level is characterized primarily by a focus on the recipient. Vorozhbitova (1999) highlights the following motives in the activity of the linguistic personality of a teacher: 1) desire for two-way subject-to-subject relations with the addressee; 2) desire to achieve communicative agreement; 3) desire for communicative consonance as a result of a harmonizing dialogue, based on the consideration of both general psychological patterns of communication and individual features of a particular addressee.

Filippova (2001, p. 95) considers the main task of this level to be the development of the ability to "take care of the addressee, choose language means of communication adequate to the interlocutor, and skillfully use rhetorical methods that facilitate communication". 
Besides, a teacher must have reflection skills, including methodological - being able to evaluate the effectiveness of grammar, orthographic, and speech exercises and their correspondence to the purpose of the lesson.

The above-mentioned traits characterise a teacher's linguistic personality as social, but they will all be refracted through its individuality.

We are convinced that exemplary linguistic personalities would not only be able to make the process of preparing children fascinating and effective but also increase the overall prestige of the teaching profession, which has fallen so dramatically in modern time. The main way of managing teachers' activities in recent years has been through financial incentives. This is undoubtedly one of the most important regulators, but scholars also point to its negative aspects (USHAKOV, 2018). The basis for the behavior of a teacher's linguistic personality should be the components of the linguo-cognitive level and, above all, its value orientations.

For more than ten years, the union of young linguists called "Anthropolinguistics" of the Philology Faculty under Ogarev Mordovia State University with the assistance of scholars from other universities (Russian and foreign ones (e.g., Masaryk University in Brno) has been doing research into linguistic personality of scholars and teachers of the past, trying to fill a gap in the history of Russian philological education (ARISKINA, 2012; 2019; ARISKINA; PULOV, 2020; PULOV, 2017)

The timeliness of this research lies in the fact that modern philological education is the result of historical evolvement, therefore it is important to understand who, how and when the foundations of linguistics were laid and how the personal characteristics of scholars have influenced on the formulation of theories, i.e., how the linguistic personality of creators of scientific discourse has been reflected in the text. It is also no secret that the role of teacher's linguistic personality in learning and educative processes is enormous, so today for pedagogy as well as for linguistics quite topical are research dealing with the study of a teacher's linguistic personality. In addition, what suggest itself is creation of modern education value orientations based on set of concepts of pre-revolutionary grammar books and nurture of important properties of a modern teacher's linguistic personality under the influence of that of philologists and methodologists of the past centuries (ARISKINA, 2015).

The purpose of this article is to analyze Apollos' linguistic personality (Baibakov Andrey Dmitrievich, 1737-1801), Bishop of Arkhangelsk and Kholmogory, and to decide whether his works can serve the basis for describing the exemplary linguistic personality of an educator-philologist, i.e. set an example for the linguistic/communicative personality of a 
modern Russian language and literature teacher and future educators. To achieve this goal, the following tasks must be performed:

1. To analyse Apollos's scientific discourse based on his work "Grammar book that guides to the perception of the Slavonic-Russian language" (1794),

2. To determine how the author's identity manifests itself in his book at the verbalsemantic, linguo-cognitive, and pragmatic levels,

3. To reveal the features of a modern teacher's linguistic personality,

4. To decide whether the linguistic personality of a priest and scholar, the author of educational grammar works, and public figure of the 18th century can serve as a model in the process of forming a linguistic personality of a modern teacher, mentor, coach, etc.

However, before confirming the hypothesis about the necessity to draw on the works of linguists and teachers of the past to nurture linguistic personality of a future educator, tutor, mentor, or facilitator, we need to go through several stages in our study and define the methodology.

\section{Methods}

To achieve this goal, one needs to divide the study into phases:

1. to reveal the problems of modern secondary schools related to the linguistic personality of a teacher (To that end, we conducted a questionnaire survey and interviewing of more than 100 respondents).

2. to analyze Apollos' linguistic personality (hereinafter - LP), paying special attention to the values and motives in its structure.

Therefore, the study draws on questionnaire forms and responses of respondents as well as the text of "Grammar book that guides to the perception of the Slavonic-Russian language" written by Apollos (Apollos (Baibakov), 1974).

The analysis of the material will be based on the methodology of George Lakoff (2004) cognitive metaphor, theory of linguistic personality by Yu.N. Karaulov (1987), concepts of the philosopher and historian of science - M.K. Petrov (2004).

Any scientific work is the quintessence of knowledge, ideas summarized in M.K. Petrov's works as sociocode, the functioning of which provides communication in various 
modes: communication (its model is communication with colleagues or partners), translation (its model - the relationship between teacher and learner) and transmutation (its model is transformation of old ideas, someone else's and your own, the emergence of the novel ones) (Petrov, 2004, p. 39).

The functioning of the sociocode reflects on each level of the structure of linguistic personality. Following Yu.N. Karaulov (1987, p. 3), we will present a scholar's linguistic personality as a three-level hierarchy: 1) the verbal-semantic level, reflecting the degree of language proficiency; 2) the linguo-cognitive level (or thesaurus), reflecting the worldview of linguistic personality; 3) the pragmatic level (or motivational), including goals, motives, interests, attitudes.

The pivot of the linguo-cognitive level and the generator of translation and transmutation of scientific knowledge, we, following G. Lakoff (2004), hold a metaphor.

Using the above technologies, we will attempt to describe the linguistic personality of the author of the grammar book of 1754 and to answer the question whether it can be considered exemplary for shaping the teacher of Russian language and literature linguistic personality (LP).

\section{Results}

The study of the teacher's LP was carried out in two aspects - synchronic (present time, 2019) and diachronic (18th century), this let us see how the teacher's personality had changed over three centuries.

Synchronous cross-section. Unfortunately, the modern secondary school is often rated by society negatively and is considered an institution that cripples children's souls in the pursuit of high rankings, upsets parents, and generally a stumbling block in family relations. Despite the variety of educational programs and the use of information technology, many adults reminisce about the "good old Soviet secondary school", and those of them who have the opportunities and resources, remove their children from school to family education. The latter, it should be noted, was often advocated by recognized teachers, methodologists of the past, for example, K.D. Ushinsky writes that he dreams "that the Russian woman, having experienced a deep pleasure to teach and develop her child, would have never conceded this pleasure to anyone without extreme necessity", because "a woman has an innate intention to teach and develop her child" (Gasparov, 1996, p. 48).

To understand the problems of modern secondary schools, we conducted a survey among successful adults (representatives of large and small businesses, company executives, 
doctors, university teaching staff, chief accountants, administrative employees, church officers, etc.). Respondents currently live not only in the Russian Federation (Moscow, Saint Petersburg, Saransk, Krasnodar, Voronezh, Yekaterinburg, Kazan, etc.), but also abroad (Wales, London, Amsterdam, Atlanta, Paris, Almaty, Pavlodar, etc.). The age of the interviewees was between 15 and 72 years. They were asked a number of questions.

The decisive ones were:

1) what image of secondary school has retained in your memory?

2) what do you think the modern secondary school is in scarcity of?

Having processed more than 100 questionnaire forms, we received the following results (below are key citations from the respondents' responses):

1. "Till now, when I feel anxious, I imagine that I am at school, standing at the blackboard...".

2. "A school is some kind of the army or a penitentiary ..."

3. "My school was good, but I studied at the time of USSR..."

4. "I remember how the teacher did everything possible to break me, it's good that my parents didn't let her, then I studied abroad."

5. "Most of all from school, I remember our last class master, thanks to whom we have learned to treat people with respect and largely to whom we became human beings."

6. "I recollect school days almost with horror. So much time is wasted, and there is no knowledge, no memories. Now, as an adult, I consciously make up for lost time.

7. "It is hard to say what a modern school is in lack of: the funding is good, there are new buildings, expensive computers... there is but soul in the school."

8. "There is a lot of indifference at school now. Teachers don't feel down as to what their learners will be in the future. The results of tests - they worry about. The unified state examination, academic Olympics and other rubbish they worry about, but what a learner feels, what is important to him, what challenges him - that is beyond their concern."

9. "They say schoolchildren are now tough, the parents are tough too, it is hard to teach for a teacher, but I do think that the school is in lack of real teachers, or they certainly are, but, very few of them in terms of the whole Russia. So very few will enjoy a good teacher."

10. "My children are in family education, because I don't see people in ordinary school who I can trust with the most precious things I have. If only my teacher had taught them... But I haven't met such in any school yet." 
11. The main thing at school is the teacher, his personality. The most important result of learning depends on this: what kind of citizens will be in our country. If teacher is rude, pushes around, humiliates those who are weaker, he hurts the child's soul, which is not yet strong, and leaves terrible scars there. If teacher treats his work as a mission, as a service, as a skilled gardener seeks to grow cultivated plants from the seeds that he receives, his garden (class) will be in order, there will be no place for weeds, poisonous herbs, all plants will develop organically. Each learner (be it an apple tree, sweet cherry, clover, cucumber, rose or a pine tree) will find its place in life and will bring beautiful fruits to society. I emphasize once again - the main thing is the teacher, more important is what kind of soul this person has, what thoughts, how and what s/he says, and above all - how and what s/he thinks."

Therefore, the main problems are the lack of soul and Teacher at school. In fact, this is one problem - it is the disappearance from the modern school of a teacher -individuality, teacher - mentor, teacher - confessor, Teacher with a capital $\mathrm{T}$, that is, an educator who constantly worries about the present and future of his/her schoolchildren.

As we can see, the role of a teacher, the role of his/her personality, linguistic personality in the academic and educative process is enormous, and it is important that the teachers themselves (first of all those who teach Russian language and literature) would realized this. Children notice absolutely everything: how teachers speak, how they gesture, how they smile. The level of speech culture should be kept high (and sometimes enhanced) by all educators. Never knowing how to pronounce correctly, a learner will not forgive a teacher mispronunciations or misspellings (by the way, the ability to forgive is also formed by the Teacher with a capital T).

Educators have to learn how to admit their mistakes, as this is a very important part of what they can teach the future generation. In this regard, I would like to underscore those integrated classes in language arts, the need for which is so often spoken about, should be taught not so much to students as to our colleagues - teachers of mathematics, geography, history, physics, chemistry, etc., because everyone must clearly understand WHAT and HOW they say, and what they should try to reach, what communicative patterns to follow. But first we have to find these samples.

We have been studying the linguistic personality of a tutor for more than 10 years (all famous ones starting from XVI century to the present day) and we can say with confidence that the teacher's LP is not changing for the better. Here are some examples of teacher's evaluative judgements in a modern secondary school: 
1. "This guy will turn a street cleaner, he doesn't want to think." What are we reading here? The teacher shuts the door on the learner, his future, and what is more - in front of the whole class. S/he also inspires disrespect for the above occupation, while it should, on the contrary, demonstrate that any honest job deserves praise and respect.

2. "Those fools who fail the Unified examination will go to serve in the army, where they will shed tears later...". Firstly, direct insult, which is absolutely unacceptable in the speech of a teacher, secondly, psychological projection of failure, and thirdly, the formation of a negative attitude to the performance of military duty. Such statements completely negate the basic values of patriotism and respect for each person in the pedagogical discourse. What kind of mutual respect can we talk about? What kind of patriotic upbringing? What kind of personality will such a teacher form? These rhetorical questions imply a gloomy future.

3. "Only mentally retarded will fail in this assignment." Even further comments are unnecessary here. It seems that some schoolchildren will then need the help of a psychotherapist, because all mental injuries come from childhood.

To spot all this in your own speech, to get appalled and start working on yourself, a teacher needs to know paragons, read the writings of great educators of the past. To study not only WHAT is written by scholars and methodologists, but also HOW. In this regard, we propose to introduce life long education courses in subject area "Linguistic personality of a tutor/mentor: history and contemporaneity". During these courses, teachers will be able not only "hear" one another, but also "hear" their colleagues from the depths of centuries. In this article, we will demonstrate this by using the description of Apollos' LP.

Diachronic cross section. Before we go to the analysis of Apollos' LP, we have to make a small retrospective journey into the 18th century - three centuries ago. Peter the First reforms were the beginning of a New time in Russian history. "The age of reason and enlightenment" - that is how the great thinkers of that time spoke of the 18th century. An important role in the development of philosophical and scientific thought was played by the enlighteners of the 18th century. Such titans of the New time as M.V. Lomonosov, V.E. Adodurov, A.A. Barsov, V. K. Trediakovsky, A.P. Sumarokov, V.N. Tatishchev, N.G. Kurganov, V.P. Svetov, P.I. Sokolov, A.S. Nikolsky and others made a breakthrough in Russian linguistics, made huge gains in the study of their native language.

Therefore, we suggest modern teachers to embrace the experience of the enlightened past, in which outstanding minds were born and created, encyclopedists whose ideas had a lead of several centuries against their time. One of these encyclopedists was Apollos. Unfortunately, modern people almost do not know this name, and teachers of Russian 
language and literature are unfamiliar with it, so in this article we consider it our duty to restore historical and cultural justice and tell our readers a little about this amazing man, a profound scholar, an outstanding personality, before we proceed to the analysis of the linguistic component part of the latter.

In 1794, in Kiev there was published a "Grammar book that guides to the perception of the Slavonic-Russian language". Its authorship belongs to Apollos (secular name Baibakov Andrey Dmitrievich, 1737-1801), Bishop of Arkhangelsk and Kholmogory. Quick facts about him: he graduated from Moscow Slavic-Greek-Latin Academy, then took the vows and became a catechist. Later on, he became the Rector of the Trinity Theological Seminary, fulfilled the duties of the Abbot of the Holy Trinity-St.Sergius Lavra, taught a course in poetry and rhetoric, organized academic theological disputes and actively took part in them. He was also the Father Superior of the New Jerusalem monastery and a member of the Russian Academy.

Apollos is the author of numerous translated and original homiletic, theological, exegetical, philological works, as well as didactic works of fiction. An excellent education allowed him in his reasoning to draw on the facts of natural sciences derived from the works by N. Copernicus, I. Newton, L. Euler, G.V. Kraft, and others. Thus, the author of this grammar book was a well - known person for his time.

Apollos defines grammar itself as the science of "speaking clearly and spelling correctly" and divides it into 4 parts: "spelling, word-formation, syntax, word stress" (Apollos (Baibakov), 1794, p. 1). However, we are primarily interested in Apollos' LP.

At the center of the verbal-semantic level of Apollos' LP is the linguistic terminology, which is not some kind of a specific property, but rather the main characteristics of any linguist's LP. The most interesting thing is that there are fragments in the Apollos metalanguage when the entire text consists of terms, i.e. the discourse is completely termed: "Grammatical segmentation/analysis. "Reading, originates from the imperfective verb read. It is a noun, neuter gender, second declension, singular nominative case" (Apollos (Baibakov), 1794, p. 17). It appears that the author realizes the goal of accurate, unambiguous translation of scientific knowledge: the use of terminology helps in this case to avoid translational interference between the author of the grammar book and the addressee. Thus, the use of terminological vocabulary becomes a specific component part not only of the verbalsemantic, but also of the pragmatic level of Apollos' LP.

Man, unlike animals, is endowed with reason and speech, so Apollos pays much attention to lexemes that denote mental and speech activity: 1) words that characterize 
intellectual activity (reason/mind/brain, notion/idea, it means, I think, cogitate/cerebrate, to cogitate, you cogitate, I regard as/consider, etc.); 2) words that characterize speech, speech activity, speech behavior (to speak, write, word, word formation, connection, verses, voice, syllable, he heard, I shall hear, etc.) (Apollos (Baibakov), 1794).

This group of words is so extensive that we decided to subdivide it into: 1) words describing oral speech: to speak, a voice, I heard, will hear, eloquent, a vowel, a consonant, to hear, is said, listen, hear, a voice, I state, you state, I squeal, I scream, I scold, I ask, will give a cry, kept asking/used to ask, will ask, I asked, used to whistle, I kept calling, kept ranting, kept asking, I laud, I speak in a deep voice, you speak in a deep voice; 2) words that characterize written speech: to write, writing, reading, I write, I read, read, to read, spelling, I shall write, a letter.

It cannot go unnoticed that the lexemes that characterize oral speech dominate in numbers over the words that denote written speech. Therefore, Apollos' LP differs from LP of many of his predecessors and contemporaries by its close attention to oral communication, this point is especially interesting for modern teachers living in one of the most communicative periods in the history of mankind.

The linguo-cognitive level manifests the grammarian's values-based attitude to an activity: "You work, but he sleeps" (Apollos (Baibakov), 1794, p. 144); to faith: "a trumpeting angel; a bearer of the God's word" (Apollos (Baibakov), 1794, p. 168); to the native language: "Look for expressions of the Russian language, which are not similar to other languages. And not to indulge in excessive care about the creation of words; so as not to take away from the beauty of language" (Apollos (Baibakov), 1794, p. 166). As we can see, when speaking about things that are important to him, the author uses an antithesis, epithets. Epithets help to emphasize the uniqueness of the language, convey the author's aesthetic attitude to the native language. In general, Apollos' attitude to language does not boil to the aestheticization of the object of research, the grammarian treats the language, the human word as a living organism, this is evidenced by the use of the metaphor: "the verbal adverbs are born..." (Apollos (Baibakov), 1794, p. 71).

Axiological attitude to a word, letter - to any language sign - is present throughout of Apollos' discourse:

Sayings are not all written in ordinary letters; but it is necessary sometimes to put capital letters or uppercase; and to use them a) from the beginning of writing; b) after full point; c) from the beginning of a new paragraph; d) in proper nouns, e.g.: Petr; e) in names of people: Russian, English; f) States: Rome, Athens; g) in reverent names: Judge, General, Senator; h) in the 
names of rivers, mountains, lands: the Dnieper, the Etna, the Morea and in the names of sciences and arts: Grammar, Pictorial Art (Apollos (Baibakov), 1794, p. 8).

The significance of letter was underscored even in the headings by preferring a letter to a numeral. It also demonstrates the author's respect not only for the word sign, but also for various ethnic groups, public service, science and art, and of the latter, the most important are grammar and painting, i.e. those areas that can display life: one - with the help of words, the other - with colors. As a result, the analogy appears: words, like brushes and paints, are a means of depicting all the nuances of the world and human life. And the above, therefore, determines respectful, reverent attitude to such an occupation as reading:

Reading books should be the main exercise of an honest person! It enlightens the mind and mends the heart! Happy are those who are content with a solitary life! They spend their time in reading unaware of boredom, which destroys idlers in the midst of luxury (Apollos (Baibakov), 1794, p. 166).

In this phrase, there is an imperative, and emotionality, and a bright imagery underpinned by epithets and metaphors - all this speaks of the author's indifferent attitude to the subject of speech. However, this statement shows the way out not only to the linguocognitive level, but also to the pragmatic one: the author sets a goal for learners, the implementation of which leads to a prosperous life. In general, if we talk about Apollos' discourse, it should be noted that it often combines a values-based attitude and a goal setting.

There are quite a lot of definitions in the proper meaning of this word in Apollos' grammar: "Grammar is the science of clean speech and correct spelling" (Apollos (Baibakov), 1794, p. 1) (here we can notice a value-based attitude to oral speech, "clean", not spoiled by people and to speech as a gift of God. Moreover, we can talk about the first step to understanding such a communicative quality of speech as cleanliness); "The name is the appellation of a thing subject to senses or reason: or the name is a part of the word, before which you can put this or those" (Apollos (Baibakov), 1794, p. 11) (of interest is variation of the definition, and the second option, located after the colon, performs the additional function of explanation).

In definitions, concepts are often interpreted through verbs meaning "to show", "to express something", etc.: "the Verb shows the beingness, action or suffering of things" (Apollos (Baibakov), 1794, p. 49); Word formation shows the property and usage changes of each word", etc. (Apollos (Baibakov), 1794, p. 1); "Adjective, expresses the quality of a thing or person" (Apollos (Baibakov), 1794, p. 12). Verbs with this meaning also appear in 
definitions- descriptions: "1) The noun that depicts things; 2) the verb that depicts acts... "(Apollos (Baibakov), 1794, p. 11). It seems that the use of verbs with the meaning of demonstration largely implements the principle of verbal clarity (demonstrativeness), which is very important for the process of translating scientific knowledge.

In definitions, there are also verbal lexemes "teach", "substitute": "the coordination of words teaches how to coordinate different words correctly" (Apollos (Baibakov), 1794, p. 1); "Pronoun is a substitute of a name and a thing" (Apollos (Baibakov), 1794, p. 44). The first definition explicitly sets the goal: to teach how. In the second case, some kind of obligation prevails. In addition, in the definition of a pronoun, the combination of a name and a thing indicates that the author of the grammar does not differentiate between the exponent and the denotation, which confirms once again his religious worldview, according to which the name and object are inseparable. This is particularly evident in the collocation "sacred words" (Apollos (Baibakov), 1794, p. 10), which are used to nominate concepts such as God, Saint, etc.

Definitions - descriptions in the text of grammar book are also numerous: "...the noun is that, which..." (Apollos (Baibakov), 1794, p. 11); "Proper noun is that, which..." (Apollos (Baibakov), 1794, p. 12); "...the perfective is that ..." (Apollos (Baibakov), 1794, p. 12); "denominal adjective is that..."; "adjective numeral is that..."; responsive is that, which "possessive is that, which..."; "paternal is that..."; "prototypical is that, which..."; "derivative is that, which..." (Apollos (Baibakov), 1794, p. 12). There are abbreviated versions of definitions-descriptions: "Pagan from vulgar tongue; pejorative of Ivan is Van'ka" (Apollos (Baibakov), 1794, p. 13).

When concepts are defined by the verb "to be used", the author manages to formulate the function of the defined concepts in the definition-description, to tell the addressee for what purposes these concepts and denotations are used:

[...] the other six are called auxiliary because they are used as follows: a pronoun is used for shortening the name/noun, a participle for shortening the noun and verb into a single phrase, an adverb for short representation of adverbial modifiers, a proposition is used for representation that adverbial modifiers belong to things or actions, a conjunction represents the reciprocity of our concepts, an interjection is used for a brief expression of the movement of mind (soul) (Apollos (Baibakov), 1794, p. 11).

Here, apart from the goal setting, there is a manifestation of verbal clarity by means of postverbal nouns "showing", "displaying". 
At the pragmatic level of Apollos' LP, there is a tendency to clarify the terminological nomination:

Active voice means action..., passive means suffering... Neuter, which is neither action nor suffering, Common has passive voice endings, and active voice meaning, ... Reciprocal is made up of active and neuter, ...Regular is subject to general rules of conjugation ... Irregular departs from general rules... . To the latter one can attribute mentioned in Slavic Grammar, stubborn and bereft of (Apollos (Baibakov), 1794, p. 50).

The last statement contains a reference to the writings of his predecessors, which points to the author's erudition and critical attitude to the scientific works of the PreLomonosov period. There are also references to the works by M.V. Lomonosov (Apollos (Baibakov), 1794, p. 10, 51). The author is familiar with the Greek and Latin works and F. Maksimov grammar book: “... The same can be said about the excess of ten grammar times introduced into Russian grammar and borrowed from the Greek grammar. The author of Novgorod grammar book on page 35 to the considerable relief of learners, removed this excess ... "(Apollos (Baibakov), 1794, p. 51) (here we can trace the goal setting aimed at an addressee - a learner). It is noteworthy that, after analyzing the tradition in presenting a particular scientific and educational material, the author expresses his own point of view on this issue: "In my opinion, it is necessary to add a fifth grammar tense to the four mentioned: pluperfect tense. The same thing in the Latin language" (Apollos (Baibakov): 1794, p. 51) (there is a transmutation of scientific knowledge, which means that we can talk about the pragmatic level of analysis of Apollos' LP).

While analysing the pragmatic level of Apollos' LP it should be said about structuredness of his grammar, about a clearly elaborated system of references (not only to authorities but also to his own reasoning in a work: "[...] about what is written in its place" (BAIBAKOV, 1794, p. 13)), about the implementation of the principle of demonstrativeness (the numerical values of the Church Slavonic letters are presented in two columns (p. 10)), about the peremptory nature of his writing ("is required to be noted [...]" (p. 13); "must be written" (p. 8); "must follow the rules" (p. 71); "ought to be" (p. 8), etc.).

So, Apollos' LP can be described as religious/spiritual, anthropocentrically-oriented, well-read, seeking substantiation of facts, demonstrativeness and objectivity, goal-setting, trying to convey knowledge to a recipient in the clearest way, with due account of learner's age, intellectual and educational facts. 


\section{Discussion}

Humanities knowledge starting from writings by E. Sapir had already began to shift the focus from the system-function-descriptive study of the object to the study of the subject (AUSTIN, 1962). The key moment in this shift to anthropocentrism was the beginning of the study of such a phenomenon as discourse, and subsequently the development of methods of discourse analysis, the study of individual discourses and the description of ethnic and professional cultures through them (BASSO, 1990; BELL, 2001; BOLDYREV, 2018; BOLDYREV; DUBROVSKAYA, 2016; BROEK; HELDER, 2017; BROWN; LEVINSON, 1987; DIJK, 1984; 1988; 1993; GRICE, 1991; JOHNSON, 2017).

The present research has also been fulfilled within the framework of the anthropocentric paradigm, the object of research - the pedagogical discourse is of interest to linguists around the world (MILOVANOVA, 1998; PULINX, 2017). Moreover, scholars' attention is drawn to both fundamental problems (for instance, why the current society underrates the status of teachers (USHAKOV, 2018) and applied issues related to the regulation of pedagogical aggression (BRAGINA; SHARONOV, 2019). However, the novelty of our research and the originality of the findings obtained are determined by the fact that the analysis of pedagogical discourse was made in two time slots - year of 2019 and the 18th century i.e., the specific properties of Russian language and literature teacher's LP were revealed in synchrony and diachrony.

Theoretically, we propose a new approach: in order to form a teacher's linguistic personality we should use a traditional basis, which implies the description and study of the linguistic personality of teachers and scholars of the past, which was demonstrated in this article.

The applied significance of the research findings is that they may be used in the practice of teaching such University disciplines as "Teacher's professional personality", "Sociolinguistics", "Communication and speech training", "Academic eloquence", etc. The research outcomes may also find application when preparing lifelong training courses for teaching staff specializing in "Linguistic personality of a teacher-mentor: history and contemporaneity".

\section{Conclusion}

When we say that the anthropocentric paradigm is an outstanding feature of the humanitarianism of our time, we should not forget that even in more distant times, the center 
of linguistic and pedagogical science was a man created by God in his own image, and this fact, indeed gave birth to the philosophy of anthropocentrism, for a man was called by God the crown of creation and only man was endowed with the gift of speech, language semiotics. The analyzed grammar book has been creating in the translation mode, conveying the sociocode from mentor to learner. This is what determined the peculiarities that we describe at different levels of Apollos' linguistic personality: the terminalization of discourse, paramount attention to speech (especially oral), pedagogical vocabulary (the main characteristics of Apollos' linguistic personality at the verbal and semantic level); key concepts in the scholar's worldview - "Work", "Learning", "Faith", "Word" ("Language"), "Grammar", "Painting", "Reading" (characteristics of the linguo-cognitive level). Apollos' linguistic personality often shows the combination of values-based and pragmatic attitudes. Thus, the analysis of terminological definitions showed that the scholar highlights the principle of verbal clarity necessary for the effective mode of sociocode translation. However, the transmutation of scientific knowledge is also characteristic of this linguistic personality, it occurs when the analysis and evaluation of other scholars' ideas generates his own thoughts of a grammarian, forms his position, his stance.

The analysis of topical issue of secondary school education arisen from inability of current teachers to organize effective communication with children, the inability to convey moral values to students, and what is worse - the inability to develop these moral values within himself/herself, as well as the analysis of Apollos' LP, an educator, philologist, spiritual leader confirmed the hypothesis that, without doubt, it is necessary to study the writings of scholars of the past to understand which linguistic personalities were at the origins of philological and pedagogical science, so that the best of the past could be transferred to the system of present education.

\section{Limitation and study forward}

The practical significance of the obtained results lies in the fact that they can be used in the teaching of university disciplines such as "Professional identity of a teacher", "Sociolinguistics", "Communication and speech training", "Academic eloquence", etc. The results will also be in demand in the preparation of professional development courses for teachers in the area of "The linguistic personality of a mentor: history and modernity".

The prospects for research are seen in expanding and deepening the knowledge of modern teachers and scholars about the linguistic personality of philologists and teachers of 
the past. This will help modern pedagogical science to form an ideal image of a mentor who will serve as a role model for young professionals who have linked their lives with the high moral goal of upbringing and teaching children, teenagers, and students.

\section{REFERENCES}

BAIBAKOV, A. D. Grammar book, that guides to the perception of Slavonic-Russian language. Kiev: Kiev-Pechersk Lavra Publ., 1974. (APOLLOS)

ARISKINA, O. Formation of value orientations in modern education on the axiological basis of 16-18th centuries grammars. Procedia - Social and Behavioral Sciences, v. 214, p. 825832, 2015. DOI: https://doi.org/10.1016/j.sbspro.2015.11.730

ARISKINA, O. L. Linguistic personality of E.B. Syreishchikov. Russian language in secondary school, v. 10, p. 40-46, 2012.

ARISKINA, O. L. Linguistic personality of scholars of Catherine the Great epoch: analysis of the verbal and semantic level. In: INTERNATIONAL SCIENTIFIC CONFERENCE DEDICATED TO THE 100TH ANNIVERSARY SINCE THE BIRTH OF A.I.

SOLZHENITSYN, 4., 2018, Saransk. Proceedings [...]. Saransk, Russia: National Research Mordovian State University named after N.P. Ogarev, 2019. p. 21-27.

ARISKINA, O. L.; DRYANGINA E. A. Expressiveness in the structure of the teacher's linguistic personality (a case study of K.D. Ushinsky). Revista Inclusiones, v. 7, n. esp., p. 153-165, 2020.

ARISKINA, O. L.; DRYANGINA, E. A. Linguistic and communicative personality: various approaches to research. Bulletin of Chelyabinsk State University, v. 25, n. 240, p. 15-18, 2011a.

ARISKINA, O. L.; DRYANGINA, E. A. Linguistic personality of the first Slavic grammarians (based on grammar books by Lavrentiy Zizania and Meletiy Smotritsky). Polythematic network electronic journal of Kuban State Agrarian University, v. 71, p. 720-734, 2011b.

ARISKINA, O. L.; PULOV, E. V. Terminological metaphors in V. A. Bogoroditsky's scientific discourse. Revista Inclusiones, v. 7, n. esp., p. 52-62, 2020.

ARISKINA, O. L.; PULOV, E. V.; NESKIN, Y. A. Concepts "Power" and "People" in the political discourse of G.A. Zyuganov. In: INTERNATIONAL SCIENTIFIC CONFERENCE, 16., 2016, Orekhovo-Zuyevo. Proceedings [...]. Moscow, Russia: Institute of Linguistics; Orekhovo-Zuyevo: Moscow State Regional Humanitarian and Technological University, 2016. p. 96-98.

ARISKINA, O. L.; YURINA, N. G. Features of the linguistic personality of V.S. Solovyovpublicist (on material of his speech "Three forces"). Utopia y Praxis Latinoamericana, v. 25, n. 5, p. 39-50, 2020. DOI: http://doi.org/10.5281/zenodo.3984201 
AUSTIN, J. L. How to do things with words: the william james lectures delivered at harvard university in 1955. Oxford: Clarendon Press, 1962.

BARANOV, M. T. (Ed.). Metodika prepodavaniya russkogo yazyka: ucheb. Posobie dlya studentov Ped. In-tov po spets. No. 2101 "Rus. yaz. i lit." [Methodology of teaching the Russian language: teaching guide for students of the pedagogical institute in the specialty No. 2101 "Russian language and literature"]. Moscow: Prosveshchenie, 1990. 368 p.

BASSO, E. B. Native Latin American cultures through their discourse. Bloomington: Folklore Institute, Indiana University, 1990.

BELL, A. Approaches to media discourse. London: Sage, 2001.

BESPAMYATNOVA, G. N. Linguistic personality of a TV presenter within the framework of a rhetorical ethos (game programs case): Summary of $\mathrm{PhD}$ thesis in philology. Yekaterinburg: Publishing house of the Ural University, 2002. 20 p.

BOLDYREV, N. N. On dominating principle of knowledge representation and meaning construction in discourse. In: INTERNATIONAL CONFERENCE ON MEANING AND KNOWLEDGE REPRESENTATION, 7., 2018, Dublin. Proceedings [...]. Dublin, Ireland: Book of abstracts, 2018.

BOLDYREV, N. N.; DUBROVSKAYA, O. G. Sociocultural specificity of discourse: the interpretive approach to language use. Procedia - Behavioral Sciences, v. 236, p. 59-64, 2016. DOI: http://dx.doi.org/10.1016/j.sbspro.2016.12.019

BRAGINA, N. G.; SHARONOV, I. A. "Pedagogical" aggression in Russian everyday communication. Russian Journal of Linguistics, v. 4, p. 975-993, 2019.

BROEK, V. D. P.; HELDER, A. Cognitive processes in discourse comprehension: passive processes, reader-initiated processes, and evolving mental representations. Discourse Processes, v. 54, n. 5-6, p. 360-372, 2017. DOI:

http://dx.doi.org/10.1080/0163853X.2017.1306677

BROWN, P.; LEVINSON, S. Politeness: Some universals in language. Cambridge: Cambridge University Press, 1987.

CHERNYAVSKAYA, V. E. The Discourse of power and the power of discourse: problems of speech manipulation: study guide. Moscow: Flinta: Nauka Publ., 2006.

COCKERILL, A. Values education in the Soviet State: The lasting contribution of V.A. Sukhomlinsky. International Journal of Educational Research, v. 50, n. 3, p. 198-204, 2011. DOI: http://dx.doi.org/10.1016/j.ijer.2011.07.005

DIJK, V. T. A. Elite discourse and racism. London: Sage Publications, 1993.

DIJK, V. T. A. News as discourse. New Jersey: Lawrence Erlbaum Associates Publishers, 1988. 
DIJK, V. T. A. Prejudice in discourse: an analysis of ethnic prejudice in cognition and conversation. Amsterdam: John Benjamins Publishing Company, 1984.

DRYANGINA, E. A. Formation of teacher's linguistic personality revisited. In: Culture of speech and business communication: proceedings of science workshop. Saransk, Russia: Krasnyi Oktybr Publ., 2008. p. 101-104.

DRYANGINA, E. A. Osobennosti proyavleniya lingvokognitivnogo urovnya yazykovoi lichnosti K.D. Ushinskogo kak avtora rabot "O pervonachalnom prepodavanii russkogo yazyka" i "Rodnoe slovo" [Features of the manifestation of the linguo-cognitive level of linguistic personality K.D. Ushinskii as the author of the works "On the initial teaching of Russian language" and "Native word"]. Politematicheskii setevoi elektronnyi nauchnyi zhurnal Kubanskogo gosudarstvennogo agrarnogo universiteta [Polythematic network electronic scientific journal of Kuban State Agrarian University], v. 91, p. 1770-1779, 2013.

ELOKHOVA, G. V. The professional language personality of a future engineer: theoretical aspect. Voprosy kognitivnoi lingvistiki [Issues of cognitive linguistics], v. 1, n. 46, p. 117$120,2016$.

FILIPPOVA, O. V. Individualnyi stil rechi uchitelya kak kategoriya pedagogicheskoi ritoriki [Individual style of a teacher's speech as a category of pedagogical rhetoric]. Moscow: Prometei, 2001. 148 p.

FILIPPOVA, O. V. Sodeistvuyushchaya strategiya i yazykovaya lichnost uchitelya-filologa [Supporting strategy and linguistic personality of a teacher-philologist]. Nauchnyi zhurnal KubGAU [Scientific Journal of Kuban State Agrarian University], v. 7, n. 81, p. 1-12, 2012.

FROLOVA, S. L. Vospitatelnyi potentsial distsipliny "Russkii yazyk i kultura rechi” i ego rol $\mathrm{v}$ formirovanii professionalnogo ideala studentov [Educational potential of the discipline "Russian language and culture of speech" and its role in forming professional ideal of students]. Russkii yazyk v shkole [Russian language at school], v. 8, p. 69-72, 2009.

GASPAROV, B. M. Language, memory, image. Linguistics of language existence. Moscow: New literary review Publ., 1996.

GRICE, P. Studies in the way of words. Cambridge, MA: Harvard University Press, 1991.

GRINEV, S. V. On lexical aspects of language evolution. fundamental and actual in language development: categories, factors, mechanisms. In: INTERNATIONAL SCIENTIFIC CONFERENCE-SCHOOL NAMED AFTER L.M. SKRELINA, 18., 2017, Moscow. Proceedings [...]. Moscow, Russia: MPGU, 2017.

GUMPERZ, J. Discourse strategies. Cambridge: Cambridge University Press, 1982.

JOHNSON, E. J. Exposing gaps in/between discourses of linguistic deficits. International Multilingual Research Journal, v. 11, n. 1, p. 5-22, 2017. DOI:

http://dx.doi.org/10.1080/19313152.2016.1258185 
KAN-KALIK, V. A. Uchitelyu o pedagogicheskom obshchenii: kn. dlya uchitelya [To a teacher on pedagogical communication: Book for a teacher]. Moscow: Prosveshchenie, 1987. $190 \mathrm{p}$.

KARASIK, V. I. Communicative approach to the study of pedagogical discourse. Russian language abroad, v. 5, n. 264, p. 4-8, 2017.

KARASIK, V. I. Yazykovoi krug: lichnost, kontsepty, diskurs [Language circle: identity, concepts, discourse]. Volgograd: Peremena, 2002. 477 p.

KARAULOV, Y. N. Russian language and linguistic personality. Moscow: Nauka Publ., 1987.

KOBYAKOVA, G. N. Rechevaya agressiya uchitelya v sovremennoi shkole [Speech aggression of a teacher in a modern school]. Vestnik Taganrogskogo instituta imeni A.P. Chekhova [Bulletin of Anton Chekhov Taganrog State Institute], v. 2, p. 24-28, 2012.

KRYSIN, L. P. Modern Russian intelligentsia: an attempt at speech analysis. Russian language in scientific coverage, v. 1, p. 90-107, 2001.

LAKOFF, G.; JOHNSON, M. Metaphors we live by. Moscow: Editorial URSS, 2004.

LEVITAN, K. M.; MEDVEDEVA, L. G. The Formation of a Professional Linguistic Personality of a Law Student in the Learning Environment of a Higher Educational Institution. Procedia - social and behavioral sciences, v. 154, p. 305-308, 2014. DOI: http://dx.doi.org/10.1016/j.sbspro.2014.10.168\\

LEVITAN, K. M.; YUGOVA, M. A. Forming an innovative professional linguistic personality of law school students on the basis of the synergetic approach. Language and culture, v. 46, p. 167-183, 2019. DOI: http://dx.doi.org/10.17223/19996195/46/10

MARTISHINA, N. V. Tsennostnyi komponent tvorcheskogo potentsiala lichnosti [Value component of the creative potential of personality]. Pedagogika [Pedagogy], v. 3, p. 48-57, 2006.

MENKOVA, N. N. Linguistic personality of a writer as a source of speech characteristics of characters: based on B. Akunin works. Moscow City Pedagogical University, Moscow, 2004.

MILOVANOVA, Z. H. V. Genre-speech specifics of pedagogical discourse. Volgograd: Peremena Publ., 1998. p. 63-64.

PETROV, M. K. Language, sign, culture. Moscow: Editorial URSS Publ., 2004.

PULINX, R. Silencing linguistic diversity: the extent, the determinants and consequences of the monolingual beliefs of Flemish teachers. International Journal of Bilingual Education and Bilingualism, v. 20, n. 5, p. 542-556, 2017. DOI:

http://dx.doi.org/10.1080/13670050.2015.1102860 
PULOV, E. V. Metaphorization of scientific discourse of the first half of the XX century (based on linguistic writings by L.V. Shcherba, V.A. Bogoroditsky, N.V. Krushevsky, I.A. Baudouin de Courtenay). Philological Sciences. Issues of theory and practice, v. 12-1, n. 78, p. 144-147, 2017.

QIU, L. et al. Personality expression in Chinese language use. International Journal of Psychology, v. 56, n. 6, p. 463-472, 2017. DOI: http://dx.doi.org/10.1002/ijop.12259

SHCHERBININA, Y. V. Pedagogicheskii diskurs: myslit - govorit - deistvovat: ucheb. posobie [Pedagogical discourse: think - speak - act: a textbook]. Moscow: Flinta, 2010. 440 p.

SHEVCHENKO, O. N. Language personality of a translator: case of B.V. Zakhoder's discourse. Volgograd State Pedagogical University, Volgograd, 2005.

SHILINA, S. A. Linguistic personality of Ivan IV: based on documents of the XVI-XVII centuries. Bryansk State University, Bryansk, 2003.

SIVTSOVA, N. V.; ARISKINA, O. L. Linguistic means of expressing knowledge in the lectures delivered by M.M. Bakhtin. Polythematic network electronic journal of Kuban State Agrarian University, v. 91, p. 1759-1769, 2013.

STOLYAROVA, E.; FEDOTOVA, M. Professional language personality of specialists in the field of human resources management and teaching foreign languages for specific purposes. Tomsk State Pedagogical University Bulletin, v. 5, p. 127-133, 2017. DOI: http://dx.doi.org/10.23951/1609-624X-2017-5-127-133

TUPITSYNA, I. N. Lexico-semantic aspects of entrepreneur's speech image in oral business discourse. Ulyanovsk State University, Ulyanovsk, 2000.

USHAKOV, K. M. Risks within the industrialization context. Journal of the Siberian Federal University, v. 11, n. 2, p. 325-327, 2018.

VALEEVA, A. F. et al. Categoriality as a form of expressiveness: expressive speech in tatar and French. Opcion, v. 34, n. 15 esp., p. 1245-1264, 2018.

VORONOVA, N. G. Tip Yazykovoi sposobnosti A. S. Makarenko [Type of language ability A. S. Makarenko]. Mir nauki, kultury, obrazovaniya [World of science, culture, education], v. 4, n. 47, p. 247-249, 2014.

VOROZHBITOVA, A. A. Sinergeticheskii aspekt vuzovskogo obrazovaniya v svete lingvoritoricheskogo podkhoda [Synergetic aspect of university education in terms of linguistic-rhetoric approach]. Alma mater. Vestnik vysshei shkoly [Alma mater. Bulletin of higher education], v. 2, p. 22-27, 1999.

YURYEVA, A. V. Lingvoritoricheskii ideal kak faktor stanovleniya professionalnoi yazykovoi lichnosti budushchego uchitelya [Linguistic-rhetoric ideal as a factor of formation of the professional linguistic personality of a future teacher]. 2002. $234 \mathrm{f}$. Thesis (Ph.D. in Pedagogical Sciences) - Sochi State University of Tourism and Resort Business, Sochi, 2002. 
ZHELTUKHINA, M. R. (Ed.). Man and his discourse - 4: collective monograph. Moscow: IL RAS, JSC Azbukovnik Publ., 2014.

\section{How to reference this article}

ARISKINA, O. L.; DRYANGINA, E. A.; LUTFULLINA, G. Writings by philologists of the past as a basis for shaping linguistic personality of a modern teacher. Rev. EntreLínguas, Araraquara, v. 7, n. esp. 2, e021027, 2021. e-ISSN: 2447-3529. DOI: https://doi.org/10.29051/el.v7iesp.2.15153

Submitted: 05/01/2021

Required revisions: 26/02/2021

Approved: $24 / 03 / 2021$

Published: 01/06/2021 